Human leucocyte antigen typing class I and class II of five patients with rheumatoid arthritis/ polymyositis overlap syndrome

\begin{tabular}{lrrlll}
\hline Patient & A loci & B loci & DRB1 & $D Q A 1$ & DQB1 \\
\hline 1 & 1,11 & 8,35 & 0101,0407 & 101,301 & 501,301 \\
2 & 29,31 & 63,71 & 1302,0701 & 102,201 & 502,303 \\
3 & 1,11 & 8,14 & 0301,0301 & 501,501 & 201,201 \\
4 & 2,68 & 42,63 & 0901,0802 & 201,401 & 301,201 \\
5 & 2,74 & 8 & 0302,1304 & 401,501 & 301,402 \\
\hline
\end{tabular}

Five patients seen at The University of Texas Medical Branch at Galveston satisfied the American Rheumatism Association criteria for $\mathrm{RA}^{5}$ and Bohan ${ }^{6}$ criteria for PM. Two white and two black women (mean age 54 years) and one black man (48 years of age) had disease ranging in duration from three to nine years. Clinical evaluation included medical histories, physical examinations, serum creatine phosphokinase levels, antinuclear antibodies (ANA) by indirect immunofluorescence on HEp-2 cells, antibodies to double stranded DNA using Crithidiae lucilae, antiribonucleoprotein, and anti-Sm antibodies by immunofixation, latex fixation test for rheumatoid factor, HLA class I and class II typing, and radiographs of hands, wrists, feet, and ankles. Electromyography was performed and muscle biopsy specimens examined in all patients.

All the patients had RA, were older than 40 and were receiving disease modifying drugs and prednisone $<7.5 \mathrm{mg} /$ day before onset of PM. Nodules were present in four of the five. None had lung involvement. Two patients had positive ANA results, and skin biopsy proven dermatomyositis. One patient was previously exposed to penicillamine.

The table shows HLA typing results. A single patient had HLA $\mathrm{DRB}^{\star} 0407$, an allele not usually associated with $R A$, and $D_{R B}{ }^{\star} 0101$, the only RA susceptibility gene found. ${ }^{7}$ HLA-B8, seen in patients with myositis, ${ }^{8}$ was present in three of the five patients, $\mathrm{DRB1} 1^{\star} 03$ in two of the five, and DQB $1^{\star} 03$ in four.

Patient 5 and anti-Jo-1 and Pl-7 antibodies. Both of these antisynthetases are associated with HLA-DR3, ${ }^{6}$ HLADQA ${ }^{\star}{ }^{*} 0401$, and ${ }^{\star} 0501$ alleles, ${ }^{9}$ all present in this patient. Patient 3 was positive for anti-PM-Scl, SS-A, and homozygous for $\mathrm{DRB} 1{ }^{\star} 0301$.

There were no serological markers universally present. Although our population was small, the phenotypes and autoantibodies resembled more closely those found in idiopathic PM than those in RA.

ARUN SHARMA BRUCE A BAETHGE JEFFREY R LISSE Division of Rheumatology,

The University of Texas Medical Branch of Galveston,

SMITA VAIDYA

Department of Pathology

JOHN D REVEILLE

Division of Rheumatology,

University of Texas Medical Center

Houston, Texas, USA

1 Parodi A, Nigro A, Rebora A. Anti-SL-Ki antibody in a patient with fatal connective overlap disease. Br $\mathcal{F}$ Dermatol 1989; 121: 243-4.

2 Hochberg M C, Feldman D, Stevens M B. Adult onset polymyositis/dermatomyositis: an analysis of clinical and laboratory features and survival in 76 patients with a review of the literature. Semin Arthritis 1986; 15: 168-78.

3 Halla J T, Koopman W J, Fallahi S, Oh S J Gay R E, Schrohenloher R E. Rheumatoid myositis: clinical and histologic features and possible pathogenesis. Arthritis Rheum 1984; 27: $739-43$

4 Oddis C V, Medsger T A, Cooperstein L A. A subluxing arthropathy associated with the anti-Jo-1 antibody in polymyositis/ dermatomyositis. Arthritis Rheum 1990; 33: 1640-5.

5 Arnett F C, Edsworthy S, Block D A, et al. The 1987 revised ARA criteria for rheumatoid arthritis. Arthritis Rheum 1987; 30: 517.

6 Targoff I N. Autoantibodies in polymyositis. Rheum Dis Clin North Am 1992; 18: 455-82.

Wheum Dis Clin North Am 1992; 18: 455-82.

Goronzy J J. The influence of HLA-DRB 1 Goronzy J J. The influence of HLA-DRB1
genes on disease severity in rheumatoid genes on disease severity in rheumatoid
arthritis. Ann Intern Med 1992; 117: 801-6.

8 Behan W M H, Behan P O, Dick H A. HLA-B8 in polymyositis. $N$ Engl $f$ Med 1978; 298: 1260-1.

9 Bohan A, Peter J B, Bowman R L, et al. A computer assisted analysis of 153 patients with polymyositis and dermatomyositis. Medicine 1977; 56: 255-86.

\section{Cytidine deaminase is not released from \\ degranulating polymorphonuclear neutrophils}

Cytidine deaminase (CD) is an enzyme involved in DNA metabolism which is particularly abundant in cytoplasm of polymorphonuclear neutrophils (PMN) and may be useful as a marker of granulocyte mediated inflammation. ${ }^{1}$ In the inflamed joints of rheumatoid arthritis, PMN are the predominant cells in synovial fluid and release CD which diffuses into the blood and provides an integrated serum measure of overall synovitis. ${ }^{2}$ Current theories argue that $\mathrm{CD}$ is released by cell lysis, by cell activation and degranulation, or by a combination of the two. ${ }^{3}$ We therefore examined these two possible mechanisms of $C D$ release from normal PMN.

PMN were obtained from the peripheral blood of eight normal volunteers by a one step sodium metrizoate-Dextran 500 separation and used at concentrations of $2 \cdot 5-9 \times 10^{5}$ cells $/ \mathrm{ml}$. Cell suspensions were subjected either to freeze-thawing in liquid nitrogen for varying times ( $0-50$ seconds) to disrupt cell membranes and cause lysis of different proportions of cells, or to stimulation with formyl methionyl leucyl phenylalanine (FMLP) in varying concentrations $\left(10^{-6}-10^{-3} \mathrm{~mol} / \mathrm{l}\right)$ to cause degranulation of different proportions of cells. Cells were spun down and supernatants collected for the assays shown below. After each procedure cells were resuspended, lysed by sustained freezing (which does not interfere with the assay for $C D$ and lactate dehydrogenase $(\mathrm{LDH})$ ) and spun down.

In the case of the degranulation experiments, cells were resuspended, divided into two aliquots, lysed either by sustained freezing or by adding Triton X-100 (which ensures complete disruption of granules),

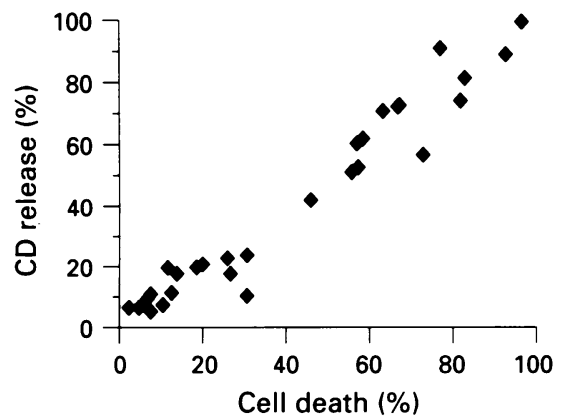

Figure 1 Correlation between cell lysis (death) and $C D$ release.

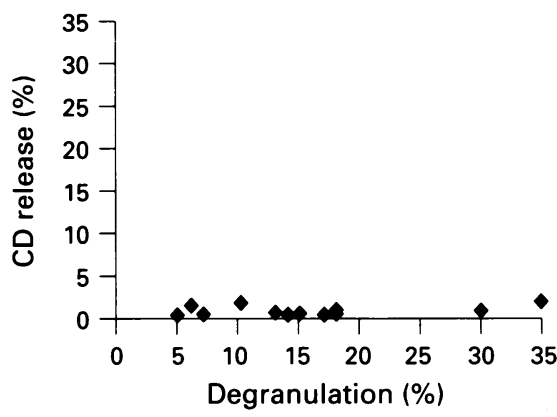

Figure 2 Relationship between cell degranulation and $C D$ release.

and spun down. These supernatants also were collected for assay.

The amount of cell lysis was assessed by measuring $\mathrm{LDH}^{4}$ released into the supernatant and comparing the value (after freezethawing) with the total $\mathrm{LDH}$ release after complete disruption of the cells and was expressed as a percentage of the total amount of LDH. The extent of PMN degranulation after stimulation was assessed by measuring myeloperoxidase (MPO) release from primary granules using standard methods ${ }^{5}$ and expressing it as a percentage of the total MPO released after lysis of all cells and granules by Triton X-100. CD concentrations were measured by standard methods. ${ }^{1}$

The proportion of cells lysed by freezethawing varied between 0 (controls) and $98 \%$, and this was mirrored by a similar range for $C D$ release. The correlation between $\mathrm{LDH}$ release (cell lysis) and CD release was $r=0.975$ ( $p<0.001$ ) (fig 1 ). The proportion of degranulation achieved varied between 0 and $35.2 \%$, but in these experiments the maximum CD release was only $2.4 \%$ and release of $\mathrm{CD}$ did not correlate significantly with that of MPO $(r=0.367, p>0.05)$ (fig 2).

These results confirm previous reports that PMN lysis causes CD release, ${ }^{2}$ but also show that FMLP stimulated degranulation does not cause $C D$ release. It seems unlikely that other stimuli to degranulation would cause $\mathrm{CD}$ release, although it might be valuable to confirm that immune complexes or aggregated IgG do not have this effect. Our findings support the notion that increased synovial fluid and serum concentrations of CD reflect intra-articular PMN lysis. It is possible that $C D$ release might be caused by other stimuli to PMN activation within inflammatory synovial fluid which do not lead to degranulation. There also remains the possibility that PMN from synovial fluid in 
inflammatory arthritis may behave differently from normal peripheral blood PMN, either because of changes in responsiveness to stimuli, or because PMN apoptosis may alter the pattern of enzyme release.

\section{MONIQUE HOEKSTRA JOHN KIRWAN Rheumatology Unit, University Department of Medicine,
Royal Infirmary, Bristol BS2 $8 H W$ United Kingdom}

Correspondence to: Dr J R Kirwan.

1 Jones D D, Roberts E L. Enzymes of DNA metabolism in clinical diagnosis, 2nd edn Aberystwyth: Chancery Publication, 1986.

2 Thompson $\mathrm{P} W$, Jones D D, Currey H L F. Cytidine deaminase activity as a measure of acute inflammation in rheumatoid arthritis. Ann Rheum Dis 1986; 45: 9-14.

3 Månsson B, Geborek P, Saxne T, Björnsson S. Cytidine deaminase activity in synovial fluid of patients with rheumatoid arthritis: relation to lactoferrin, acidosis and cartilage proteoglycan release. Ann Rheum Dis 1990; 49. 594-7.

4 Cabaud P G, Wroblewski F. Coloric measurement of lactic dehydrogenase activity of body fluids. Am f Clin Pathol 1958; 30: 234-6.

5 Suzuki K, Ota H, Sagawa S, Sakatari T, Fujikura T. Assay method for myeloperoxidase in human polymorphonuclea leucocytes. Anal Biochem 1983; 132: 345-52.

\section{Carpal tunnel syndrome as initial manifestation of inflammatory connective tissue diseases}

Carpal tunnel syndrome (CTS) is the most common entrapment neuropathy presented at rheumatology consultation. Most CTS are considered idiopathic or related to activities that require repetitive flexor handwork. However, it is well known that CTS may also occur in the context of inflammatory connective tissue diseases (ICTD), ${ }^{1-3}$ and may precede other manifestations of these associated inflammatory disorders by weeks or months. ${ }^{4}$ In order to determine how frequently CTS appears as the first manifestation of ICTD, we undertook a prospective study of patients referred to our unit with suspected CTS.

From January 1983 to December 1992, 324 consecutive patients were evaluated and included in the study. CTS was defined by the presence of a suggestive clinical picture together with a positive Tinel or Phalen sign,
Aetiologies of carpal tunnel syndrome

\begin{tabular}{lrc}
\hline Aetiology & No & $\%$ \\
\hline Idiopathic & 122 & $60 \cdot 7$ \\
Hand work associated & 24 & $11 \cdot 8$ \\
ICTD (n=18) & 12 & 9 \\
RA & 2 & \\
Primary SS & 2 & \\
UCTD & 1 & \\
CREST & 1 & \\
HLA-B27 & 17 & $8 \cdot 5$ \\
Diabetes & 15 & $7 \cdot 5$ \\
Hypothyroidism & 2 & 1 \\
CCPD & 2 & 1 \\
Ganglion & 1 & $0 \cdot 5$ \\
Lymphoedema & 201 & 100 \\
Total &
\end{tabular}

ICTD = Inflammatory connective tissue diseases RA = rheumatoid arthritis; SS = Sjögren's syndrome; UCTD = undifferentiated connective tissue disease; CREST = calcinosis, Raynaud's phenomdisease; CREST = calcinosis, Raynaud's phenom-
enon, oesophageal dysmotility, sclerodactyly, telangiectasia; CCPD = calcium pyrophosphate dihydrate crystal deposition disease.

or characteristic electrodiagnostic findings. Patients with previous or concomitant inflammatory rheumatic disease were excluded. All patients underwent anamnesis, physical examination, blood cell count, urine analysis, elemental biochemistry, proteinogram, serum rheumatoid factor assay and electrodiagnosis. Thyroid hormones were determined only if hypothyroidism was suspected clinically or by typical laboratory findings (hypercholesterolaemia or increased creatine phosphokinase). Of the 324 patients initially studied, only 201 fullfilled the inclusion criteria and were followed during a mean period of 13.6 months (range 6-24).

The mean age of the population was 52.8 (SD 10.3) years; $92 \%$ were women. Patients had suffered symptoms of CTS for a mean period of 38 (22) weeks before their first consultation in our clinic. The table summarises the different aetiologies. In 18 patients CTS was the first manifestation of ICTD, with a mean period of 10.4 months (range 1-34) between the onset of CTS symptoms and the definitive diagnosis of related ICTD. Rheumatoid arthritis was the inflammatory disease detected most commonly in the follow up of CTS patients. It was initially defined following the 1958 American Rheumatism Association (ARA) criteria. ${ }^{6}$ During the last four years of the study, the 1987 ARA criteria ${ }^{7}$ were used and previous rheumatoid arthritis diagnoses were reviewed.
Of the different parameters tested, only serum rheumatoid factor and period of evolution before diagnosis were significantly different between the ICTD and non-ICTD groups. Serum rheumatoid factor was detected in $50 \%$ of the ICTD group, compared with $3 \cdot 2 \%$ of the non-ICTD group ( $<<0.001$, Fisher test). Symptoms before diagnosis were present for 23.1 (21.4) weeks and $39.4(21.8)$ weeks in the ICTD and non-ICTD groups, respectively $(p<0.01$, Student's $t$ test), probably reflecting a more severe clinical picture in ICTD patients.

In conclusion, our study found CTS to be the first manifestation of ICTD in $9 \%$ of cases (95\% confidence interval 5 to $13 \cdot 2 \%$ ). In addition, serum rheumatoid factor could be a marker of those patients with CTS who may progress to ICTD, having a positive predictive value of $69.1 \%$ and negative predictive value of $96.9 \%$. Thus we propose that seropositive CTS patients should be followed for a period of 10-12 months because of their high risk of developing an inflammatory rheumatic disease.

\section{ISIDORO GONZÁLEZ-ALVARO INMACULADA CARVAJAI MIGUEL ESTEVEZ JUAN PEDRO LÓPEZ-BOTE JUAN PEDRO LOPEZ-BOTE Rheumatology Section, Hospital de la Princesa, Madrid, Spain}

Correspondence to: Dr Isidoro González Alvaro, Sección de Reumatología, Hospital de la Princesa, c/ Diego de Leon 62, 28006 Madrid, Spain.

1 Sheon R P, Moskowitz R W, Goldberg V M, eds. The wrist and hand. In: Soft tissue rheumatic pain, 2nd edn. Philadelphia: Lea \& Febiger, 1987; 112-40.

2 Nakano K K. Entrapment neuropathies. In: Kelley W N, Harris E D, Ruddy S, Sedge C B, eds. Textbook of rheumatology, 3nd edn. Philadelphia: WB Saunders Company, 1989; 1844-59.

3 Phalen G S. The carpal tunnel syndrome. f Bone foint Surg Am 1966; 48: 211-28.

4 Hadler N M. Nerve entrapment syndromes. In: McCarthy D J, Koopman W J, eds. Arthritis and allied conditions, 12th edn. Philadelphia: Lea \& Febiger, 1993; 1619-859.

5 Sidiq M, Kirsner A B, Sheon R P. Carpal tunnel syndrome. First manifestation of systemic lupus erythematosus. $\mathscr{f} A M A$ 1972; 222: 1416-7.

6 Ropes M W, Bennet G A, Cobb S, et al. 1958 Revision of diagnostic criteria for rheumatoid arthritis. Bull Rheum Dis 1958; 9: 175-6.

7 Arnett F C, Edworthy S M, Block D A, et al. The American Rheumatism Association 1987 revised criteria for the classification of rheumatoid arthritis. Arthritis Rheum 1988; 31: 315-24.. 